\title{
A Comparison of Some Parameters of Football Players According to the Leagues They Play $\mathrm{In}^{*}$
}

\author{
Tahir Kilic ${ }^{1}$, Mehmet Ali Anil Tosur ${ }^{1}$ \\ ${ }^{1}$ Akdeniz University, Turkey \\ Correspondence: Tahir Kilic, Akdeniz University, Turkey.
}

Received: September 2, 2018

Accepted: September 16, 2018

Online Published: September 18, 2018

doi:10.11114/jets.v6i11.3591

URL: https://doi.org/10.11114/jets.v6i11.3591

\begin{abstract}
The purpose of this study was to compare some parameters of football players playing in 3rd League, BAL (Regional Amateur League) and SAL (Super Amateur League) according to the leagues they play in.

Body height, body weight, body mass index, age, age of becoming a registered football player, vertical jump, anaerobic power, shuttle run, aerobic capacity $\left(\mathrm{MaxVO}_{2}\right)$, leg strength, back strength, right-hand grip strength and left-hand grip strength parameters were measured in this study. ANOVA test, which is one of the parametric tests, were applied for the analysis of the data and significance level of $\mathrm{p}<0.05$ was sought.

In conclusion, significant differences among the leagues were found according to height, vertical jump, anaerobic power, shuttle run, aerobic capacity, leg strength and back strength. However, no significant differences were found on body mass index, age, and age of becoming a registered football player, right-hand grip strength and left-hand grip strength parameters.
\end{abstract}

Keywords: football, league, physical fitness

\section{Introduction}

Football is one of the most popular sports branches in Turkey and the world. Besides its attractiveness, the fact that it can be applied in every society with pleasure provided it to reach to large masses and become the focus of interest for millions of people. The interaction of science and sports sciences improves the working conditions of football players and by this way improvement that provide the audiences with better watching, enjoying and getting pleasure are ensured. Thus, that interaction accelerates the progress of football and its spread to large masses (Günay and Yüce, 2008). Especially local leagues of the countries and international football organizations such as Olympic Games and world cup are organized and followed carefully by the large masses of the societies. As football, which attracts many people's interest from various languages, religions, races and geographic regions, is a sports branch that is followed by large masses, thousands of people go to the stadiums to watch the football matches, and they blow off steam by shouting. The impact of the football on the people occurs not only during the match times. It is followed closely by following sports programs and newspapers also after the matches (Bayrak, 2011).

Football is a kind of team sports in which behaviors that are aimed to score a goal and not concede a goal are exhibited in consequence of the runs made at different tempos and the motions realized with a ball that can be controlled and where it will go can be estimated (Buğdayc1, 2000). The fact that it is a sports branch that requires versatile skills, and in which an irregular and sometimes very severe aneorobic-weighted game character is reflected on basic aerobic endurance characteristics has caused many scientific studies to be conducted on football players. (Acckada et al., 1999). These technological and scientific developments caused changes and advancements in football. Today's football has become a competition with high coordination that is played under field and time pressure, has a high tempo and requires endurance (Karatepe, 2009).

*Ethics Committee Approval: It was approved by Akdeniz University Faculty of Medicine Clinical Researches Ethics Committee70904504/609 number 30.12.2016 date no: 690 decisions. Ethics Committee Code: 2012-KAEK-20

This research was produced from Mehmet Ali Anil TOSUR's (2018) Akdeniz University Institute of Health Sciences Master's Thesis titled "A Comparison of Some Parameters of Football Players. "Thesis Counselor: Asst. Prof. Tahir KILIC. 
The fact that football is played on a wide field and duties that are assigned to its players vary, makeit necessary to evaluate physical and physiological requirements in terms of player positions (Marancı and Müniroğlu, 2001). Football is a game in which aerobic movements and short time anaerobic type movements combine with ball skills throughout the game (Bangsbo, 1994). It was reported that aerobic and anaerobic capacity is a high-density interval physical activity that is required to be developed well (Roescher et al, 2010). Although football is regarded as an interval activity, the game lasts for a long period of time. It has the characteristics of many short and high-density exercises that contain critical periods in it (Meckel et al, 2009). Interval physical activities are the actions that require skills together with various instincts. Exhibited physical activity, runs, jumps, tackles, explosive power, and strikes have important places in football (Garganta et al., 1992). Football is a game that requires high physical capabilities in a high and changing tempo and these capabilities are exhibited during the trainings and the games. Some researchers conducted put forth the importance of maximum power and maximal effort in this field (Davis et al., 1992). In order to be an elite player and outmaneuver the rivals in the games in today's football, it is necessary for the football players to have high level physical and physiological characteristics. The importance of physical and physiological characteristics in football was put forth in many scientific studies (Bizati, 2013).

The purpose of the study is to compare some of the parameters of the football players playing in the $3^{\text {rd }}$ League, BAL (Regional Amateur League) and SAL (Super Amateur League). Taking into account the leagues that the teams play in, it is thought that the results obtained will be a guide in transferring football players, following the progress of the players, and determining physical and physiological characteristics of the players and also for the football players they will create possibilities of competing in the leagues that is suitable for them.

\section{Method}

Participants

The research was conducted with the football players from Kemer Belediyespor and Kizllcabolükspor from the $3^{\text {rd }}$ League, Municipality of Bucak Oğuzhanspor and Kepez Belediyespor from the Regional Amateur League, Antalya Sanayispor and Konyaaltı Belediyespor from the Super Amateur League in the 2017-2018 season. The participants consisted of total 6 teams and 132 male football players $n=49$ professional football players from the $3^{\text {rd }}$ League, $n=46$ amateur football players from the Regional Amateur League and $n=37$ amateur football players from the Super Amateur League. Of the football players, $n=49$ were the players who play football professionally, $n=35$ were the players who downgraded from playing as a professional to playing as an amateur, and $n=48$ were the amateur players who never played professionally.

\section{Data Collection Tools and Data Collection}

\section{Measurement of Body Height}

Measurements of body heights were done by SECA brand precision height/weight measuring station. In measuring the heights, while the participants stood on foot at the vertical position, caliper sliding on the scale was adjusted as it would touch to the highest point of the head (apex). The heights were recorded with $1 \mathrm{~mm}$ precision (Gordon et al., 1989).

\section{Measurement of Body Weight}

Measurements of body weights of the participants were done by SECA brand precision height/weight measuring station, whose precision level is $0.1 \mathrm{~kg}$. The participants wore only short, they were in barefoot and at anatomical position and the measurements were recorded in $\mathrm{kg}$.

\section{Measurement of Body Mass Index}

Data were calculated by "Body Mass Index" which explains the distribution of the weight according to the height by using height and weight values obtained (Tamer, 2000).

$$
\text { BMI= weight } / \text { height }^{2}=\mathrm{kg} / \mathrm{m}^{2}
$$

\section{Measurement of Hand Grip Strength}

Measurements of hand grip strength were done by using Takei brand Hand Grip (Hand Dynamometer). Measurements were done after the participants warmed up for five minutes, while they were standing on foot, the arm was positioned at an angle of $45^{\circ}$ to the body, and without bending the arms and touching to the body. This was done for both right and left hands and it was repeated twice after a trial for each hand. The best results for right and left hands were recorded in $\mathrm{kg}$.

\section{Measurement of Back Strength}

Measurements of back strength were done by using Takei brand back and leg (back and lift) dynamometer. The participants put their feet on dynamometer table while they bend their knees, with stiff arms, straight back and the body 
leans forward slightly. Then, they hold the dynamometer handle and pull it upward vertically at a maximum rate by using their back muscles (Zorba et al., 2009; Weineck, 2011). The participants warmed up for five minutes before the measurement. They were asked to put their feet on the dynamometer table while their knees were stiff. At this position and with stiff arms, straight back and the body leaned forward slightly; they were asked to pull the dynamometer handle that they held vertically upward at a maximum rate. This pull up was repeated twice after a trial and the best score for each participant was recorded.

\section{Measurement of Leg Strength}

Measurements of leg strength were done by using Takei brand back and leg (back and lift) dynamometer. The dynamometer runs according to the pressure principle. When an external power is applied to the dynamometer, steel wire strains and moves the needle. Thus, the indicator on the dynamometer detects how much power an individual exerted in kilograms $(\mathrm{kg})$. The participants warmed up for five minutes before the measurement. At the end of the warm-up, they were asked to put their feet on the dynamometer table while their knees were bent. They put their feet on the dynamometer table while their knees were bent, with stiff arms, knees were bent at an angle of between 130-140 degrees, straight back and the body leaned forward slightly. At this position, they pulled the dynamometer handle that they held upward at a maximum rate by using their legs (Ozer, 2001).

\section{Vertical Jump Test and Calculating Anaerobic Power}

For the measurements of vertical jump, Takei brand digital jump meter with $0.1 \mathrm{~cm}$ precision was used. Zorba (2009) stated that the reliability of the test was between $0.90-0.97$ based on the reliability studies conducted. After the LCD screen is fit by a belt around their waist and the belt is adjusted, the participants bend their knees $90^{\circ}$ and jump upwards with two feet. After the jump, when landing the participants try to fall in the round plastic field that is laid on the ground. After landing onto the ground, if steps are taken forward or backward, then the jump is declared void and repeated again. The jumps were repeated twice and the highest scores were recorded. In calculating the anaerobic power, $\mathrm{P}=\sqrt{ } 4.9$ (Weight) $\sqrt{ }$ Dn formula (Fox et al.,1988;Sevim,1995;Zorba, 1999; Tamer,2000;Günay et al.,2006) was used. "P" in the formula symbolizes power in kilogram-meter/second, and, "Dn" symbolizes vertical jump distance in meters. Body weights and vertical jump distances of the participants were placed in the formula and anaerobic powers of the individuals were found in kilogram meter/second $(\mathrm{kgm} / \mathrm{sec})$.

Anaerobic power $(\mathrm{kg} . \mathrm{m} / \mathrm{sec})=.\sqrt{ } 4.9 \mathrm{x}$ body weight $) \mathrm{x} \quad \sqrt{ }$

$\mathrm{D}=$ distance jumped vertically (m.)

Shuttle Run Test and Calculating Aerobic Capacity

Aerobic capacities of the participants were measured by Shuttle Run Test. Measurements were made on grass grounds. This is a test that consists of 23 levels and $20 \mathrm{~m}$ distance is run continuously between two lines with an initial running velocity of $8.5 \mathrm{~km} . \mathrm{h}-1$ ( $9 \mathrm{sec})$ which increases by $0.5 \mathrm{~km}$.h each minute. One beep that was recorded states that the shuttle ended and 3 beeps state that the next level started. The athletes were warmed up for a short time before the test and they were motivated. It was stated that at the end of each shuttle they were expected to put their foot on or beyond the $20 \mathrm{~m}$ line, if they arrive before the beep, they should wait for the beep, and continue running after the beep. By making shuttle run test, the participants tried to adjust their running tempos according to the beeps that accelerate at certain speeds (Duration between the beeps get shorter in time.). If a participant becomes exhausted or unable to keep up with the beep recording of a shuttle twice, then the test was terminated for him. Number of levels and shuttles were recorded. A study were conducted in 1988, 36 male and 38 female athletes participated it, and shuttle run test and $5 \mathrm{~km}$ running test were compared. In this test, Ramsbottom et al. (1988) found strong correlation between $\mathrm{MaxVO}_{2}$ and shuttle level $(\mathrm{r}=0.92)$ and between $5 \mathrm{~km}$ running test and $\mathrm{MaxVO}_{2}(\mathrm{r}=-0.94)$. When the two tests were compared, a strong correlation $(\mathrm{r}=-0.96)$ were detected. In order to determine the aerobic capacity, in converting shuttle levels obtained in the end of the test to $\mathrm{MaxVO}_{2}$, the table and the method that Ramsbottom et al. (1988) developed was used (As cited in. Aslan and Koc, 2015).

\section{Personal Information Form}

The information of the football players participating in the study were obtained by using personal information form. The scores they got during the measurements were recorded in these personal information forms.

Analysis of the Data

In this study, statistical results were calculated by using SPSS 23 package software. Frequency (n), arithmetic average $(\mathrm{X})$, and standard deviation (Ss) of measured and tested variables of all of the participants playing football in different leagues were calculated according to the teams. For the test of normality of the data used in the study, Kolmogorov Smirnov test was used. Test of normality was conducted and the data showed normal distribution. ANOVA test, which is 
one of the parametric tests, was used as the data fit the normal distribution. The significance level of $p<0.05$ was accepted statistically.

\section{Results}

Table 1. General findings of the football players participating in the study

\begin{tabular}{lll}
\hline Variables & $\mathbf{n}$ & $\mathbf{X} \pm \mathbf{S s}$ \\
\hline Height $(\mathbf{c m})$ & 132 & $177.75 \pm 6.19$ \\
Body Weight $(\mathbf{k g})$ & 132 & $74.08 \pm 7.63$ \\
BMI $(\mathbf{k g} / \mathbf{m} 2)$ & 132 & $23.40 \pm 1.63$ \\
Age & 132 & $23.83 \pm 4.46$ \\
ABRFP(Age of Becoming a Registered Football Player) & 132 & $12.75 \pm 4.32$ \\
\hline
\end{tabular}

Of the 132 male football players who participated in our research sample, the average height was $177.75 \pm 6.19$, the average body weight was $74.08 \pm 7.63$, the average BMI was $23.40 \pm 1.63$, the average age was $23.83 \pm 4.46$, and the average ABRFP was $12.75 \pm 4.32$.

Table 2. Variables of height, weight, body mass index, age, and age of becoming a registered football player according to the leagues

\begin{tabular}{|c|c|c|c|c|c|c|c|}
\hline Variables & Leagues & $\mathbf{n}$ & $\mathrm{X} \pm \mathrm{Ss}$ & sd & $\mathbf{F}$ & $\mathbf{p}$ & $\begin{array}{c}\text { Significant } \\
\text { Difference (tukey) }\end{array}$ \\
\hline \multirow[t]{4}{*}{ Body Height (cm) } & 1. 3. League & 49 & $179.52 \pm 6.50$ & $2-129$ & 3.635 & .029 & $1-3$ \\
\hline & 2. BAL & 46 & $177.21 \pm 5.21$ & & & & \\
\hline & 3. SAL & 37 & $176.09 \pm 6.45$ & & & & \\
\hline & Total & 132 & $177.75 \pm 6.19$ & & & & \\
\hline \multirow[t]{4}{*}{ Body Weight (kg) } & 1. 3. League & 49 & $75.80 \pm 7.98$ & $2-129$ & 2.284 & .106 & - \\
\hline & 2. BAL & 46 & $73.60 \pm 6.28$ & & & & \\
\hline & 3. SAL & 37 & $72.39 \pm 8.40$ & & & & \\
\hline & Total & 132 & $74.08 \pm 7.63$ & & & & \\
\hline \multirow[t]{4}{*}{ BMI $\left(\mathbf{k g} / \mathbf{m}^{2}\right)$} & 1. 3. League & 49 & $23.46 \pm 1.48$ & $2-129$ & 0.106 & .900 & - \\
\hline & 2. BAL & 46 & $23.40 \pm 1.56$ & & & & \\
\hline & 3. SAL & 37 & $23.30 \pm 1.92$ & & & & \\
\hline & Total & 132 & $23.40 \pm 1.63$ & & & & \\
\hline \multirow[t]{4}{*}{ Age } & 1. 3. League & 49 & $23.34 \pm 3.50$ & $2-129$ & 1.201 & .304 & - \\
\hline & 2. BAL & 46 & $23.58 \pm 4.00$ & & & & \\
\hline & 3. SAL & 37 & $24.78 \pm 5.91$ & & & & \\
\hline & Total & 132 & $23.83 \pm 4.46$ & & & & \\
\hline \multirow[t]{4}{*}{ ABRFP* } & 1. 3. League & 49 & $13.14 \pm 3.61$ & $2-129$ & 0.500 & .608 & - \\
\hline & 2. BAL & 46 & $12.26 \pm 3.85$ & & & & \\
\hline & 3. SAL & 37 & $12.83 \pm 5.62$ & & & & \\
\hline & Total & 132 & $12.75 \pm 4.32$ & & & & \\
\hline
\end{tabular}

1= 3.League, $2=$ Regional Amateur League, $3=$ Super Amateur League.*ABRFP:Age of Becoming a Registered Football Player

Characteristics of the participants in body weight $[\mathrm{F}(2-129)=2.284 ; \mathrm{p}>.05] ; \mathrm{BMI}[\mathrm{F}(2-129)=0.106 ; \mathrm{p}>.05]$; age $[\mathrm{F}(2-129)=1.201 ; \mathrm{p}>.05]$ and ABRFP $[\mathrm{F}(2-129)=0.500 ; \mathrm{p}>.05]$ dimensions do not differ according to the leagues. However, characteristics of the participants in height $[\mathrm{F}(2-129)=3.635 ; \mathrm{p}<.05]$ dimension differ significantly according to the leagues. In this dimension, heights of the football players playing in the 3. League $(179.52 \pm 6.50)$ is higher when compared to the heights of the football players playing in the Super Amateur League (176.09 \pm 6.45$)$. 
Table 3. Comparison of vertical jump, anaerobic power, shuttle run, aerobic capacity and strength measurements according to the leagues

\begin{tabular}{|c|c|c|c|c|c|c|c|}
\hline Variables & Leagues & $\bar{n}$ & $\mathrm{X} \pm \mathrm{Ss}$ & sd & $\mathbf{F}$ & $\mathbf{p}$ & $\begin{array}{l}\text { Significant } \\
\text { Difference } \\
\text { (tukey) }\end{array}$ \\
\hline \multirow[t]{3}{*}{ Vertical Jump (cm) } & 1. 3. League & 49 & $59.08 \pm 7.38$ & \multirow[t]{3}{*}{$2-129$} & \multirow[t]{3}{*}{8.371} & \multirow[t]{3}{*}{.000} & \multirow[t]{3}{*}{$1-3$} \\
\hline & 2. BAL & 46 & $56.89 \pm 5.62$ & & & & \\
\hline & 3. SAL & 37 & $53.43 \pm 5.66$ & & & & \\
\hline \multirow{3}{*}{$\begin{array}{l}\text { Anaerobic } \\
(\mathrm{kg} . \mathrm{m} / \mathrm{sec})\end{array}$} & 1. 3. League & 49 & $128.90 \pm 17.13$ & \multirow[t]{3}{*}{$2-129$} & \multirow[t]{3}{*}{7.212} & \multirow[t]{3}{*}{.001} & \multirow[t]{3}{*}{$1-3$} \\
\hline & 2. BAL & 46 & $122.76 \pm 12.25$ & & & & \\
\hline & 3. SAL & 37 & $116.63 \pm 14.64$ & & & & \\
\hline \multirow[t]{3}{*}{ Shuttle Run } & 1. 3. League & 49 & $102.43 \pm 16.69$ & \multirow[t]{3}{*}{$2-129$} & \multirow[t]{3}{*}{10.834} & \multirow[t]{3}{*}{.000} & $2-1$ \\
\hline & 2. BAL & 46 & $114.85 \pm 13.00$ & & & & $2-3$ \\
\hline & 3. SAL & 37 & $100.73 \pm 16.86$ & & & & \\
\hline \multirow{3}{*}{$\begin{array}{lr}\text { Aerobic } & \text { Capacity } \\
\left(\operatorname{MaxVO}_{2}\right) & (\mathrm{ml} / \mathrm{kg} / \mathrm{min})\end{array}$} & 1. 3. League & 49 & $52.47 \pm 5.06$ & \multirow[t]{3}{*}{$2-129$} & \multirow[t]{3}{*}{11.193} & \multirow[t]{3}{*}{.000} & $2-1$ \\
\hline & 2. BAL & 46 & $56.24 \pm 3.59$ & & & & $2-3$ \\
\hline & 3. SAL & 37 & $52.08 \pm 4.96$ & & & & \\
\hline \multirow[t]{3}{*}{ Leg Strength (kg) } & 1. 3. League & 49 & $160.43 \pm 25.20$ & \multirow[t]{3}{*}{$2-129$} & \multirow[t]{3}{*}{16.850} & \multirow[t]{3}{*}{.000} & $1-3$ \\
\hline & 2. BAL & 46 & $163.00 \pm 29.75$ & & & & $2-3$ \\
\hline & 3. SAL & 37 & $132.57 \pm 2.49$ & & & & \\
\hline \multirow[t]{3}{*}{ Back Strength (kg) } & 1. 3. League & 49 & $154.10 \pm 25.82$ & \multirow[t]{3}{*}{$2-129$} & \multirow[t]{3}{*}{6.573} & \multirow[t]{3}{*}{.002} & \multirow[t]{3}{*}{$1-3$} \\
\hline & 2. BAL & 46 & $144.85 \pm 25.92$ & & & & \\
\hline & 3. SAL & 37 & $134.86 \pm 21.49$ & & & & \\
\hline Right Hand & 1. 3. League & 49 & $42.37 \pm 6.83$ & \multirow[t]{3}{*}{$2-129$} & \multirow[t]{3}{*}{0.638} & \multirow[t]{3}{*}{.530} & \multirow[t]{3}{*}{-} \\
\hline \multirow{2}{*}{ Strength (kg) } & 2. BAL & 46 & $42.94 \pm 7.75$ & & & & \\
\hline & 3. SAL & 37 & $41.22 \pm 6.02$ & & & & \\
\hline Left Hand & 1. 3. League & 49 & $41.34 \pm 6.13$ & $2-129$ & 0.248 & .781 & - \\
\hline \multirow[t]{2}{*}{ Strength (kg) } & 2. BAL & 46 & $40.82 \pm 7.61$ & & & & \\
\hline & 3. SAL & 37 & $40.35 \pm 5.46$ & & & & \\
\hline
\end{tabular}

Characteristics of the participants in right hand grip strength $[\mathrm{F}(2-129)=0.638 ; \mathrm{p}>.05]$ and left hand grip strength $[F(2-129)=0.248 ; p>.05]$ dimensions do not differ according to the leagues. Characteristics of the participants in vertical jump and anaerobic power dimensions differ according to the leagues $[\mathrm{F}(2-129)=8.371 ; \mathrm{p}<.05]$ and $[\mathrm{F}(2-129)=7.212 ; \mathrm{p}<.05]$. Regarding this dimension, vertical jump (59.08 \pm 7.38$)$ and anaerobic power (128.90 \pm 17.13$)$ characteristics of the football players playing in the 3. League is higher than vertical jump (53.43 \pm 5.66$)$ and anaerobic power $(116.63 \pm 14.64)$ characteristics of the football players playing in the Super Amateur League. Characteristics of the participants in shuttle run and aerobic capacity dimensions differ according to the leagues $[\mathrm{F}(2-129)=10.834 ; \mathrm{p}<.05]$ and $[\mathrm{F}(2-129)=11.193 ; \mathrm{p}<.05]$. Regarding this dimension, shuttle run $(114.85 \pm 13.00)$ and aerobic capacity $(56.24 \pm 3.59)$ characteristics of the football players playing in the Regional Amateur League is higher than shuttle run $(102.43 \pm 16.69)$ and aerobic capacity $(52.47 \pm 5.06)$ characteristics of the football players playing in 3. League and shuttle run $(100.73 \pm 16.86)$ and aerobic capacity $(52.08 \pm 4.96)$ characteristics of the football players playing in the Super Amateur League. Leg strength characteristics of the participants differ according to the leagues $[\mathrm{F}(2-129)=16.850 ; \mathrm{p}<.05]$ and $[\mathrm{F}(2-129)=13.477 ; \mathrm{p}<.05]$. Regarding this dimension, leg strength $(132.57 \pm 21.49)$ characteristics of the football players playing in the Super Amateur League is lower than leg strength (160.43 \pm 25.20$)$ characteristics of the football players playing in the 3. League and leg strength $(163.00 \pm 29.75)$ characteristics of the football players playing in the Regional Amateur League. Back strength characteristics of the participants differ according to the leagues $[F(2-129)=6.573$; $\mathrm{p}<.05]$ and $[\mathrm{F}(2-129)=3.271 ; \mathrm{p}<.05]$. Regarding this dimension, back strength $(154.10 \pm 25.82)$ characteristics of the football players playing in the 3. League is higher than back strength (134.86 \pm 21.49$)$ characteristics of the football players playing in the Super Amateur League.

\section{Discussion}

When the heights of the 132 male football players who participated in our research sample were compared, it was determined that average height of the 3. League was $179.52 \pm 6.50 \mathrm{~cm}$, the average height of the Regional Amateur League (BAL) was $177.21 \pm 5.21 \mathrm{~cm}$ and the average height of the Super Amateur League (SAL) was $176.09 \pm 6.45 \mathrm{~cm}$. In this context, a significant correlation in favor of the 3. League between the 3. League and SAL was found. Heights of the football players who participated in the study of 3. League team was found as $179.58 \pm 6.1 \mathrm{~cm}$ by Marangoz (2008). Erkmen et al. (2005) reported the average height of the 3 . League as $176.4 \pm 1.29 \mathrm{~cm}$. In the body weight comparison according to the leagues in our study, it was found that average body weight of the 3 . League was $75.80 \pm 7.98 \mathrm{~kg}$, the average body weight of the BAL was $73.60 \pm 6.28 \mathrm{~kg}$ and average body weight of the SAL was $72.39 \pm 8.40 \mathrm{~kg}$. Any statistically significant correlation was not found between the 3. League, BAL, and SAL in terms of body weight. The body weights of the football players who participated in the study of 3. League team was detected as $71.99 \pm 7.5 \mathrm{~kg}$ by 
Marangoz (2008). Erkmen et al. (2005) found that the average body weight of the 17 football players playing in the Turkish 2. League was $74.53 \mathrm{~kg}$. Regarding the comparison of BMI according to the leagues in our study, it was found that the average BMI of the 3 . League was $23.46 \pm 1.48 \mathrm{~kg} / \mathrm{m}^{2}$, average BMI of the BAL was $23.40 \pm 1.56 \mathrm{~kg} / \mathrm{m}^{2}$, average BMI of the SAL was $23.30 \pm 1.92 \mathrm{~kg} / \mathrm{m}^{2}$. Any statistically significant correlation was not found between the 3 . League, $\mathrm{BAL}$, and SAL in terms of BMI. When the ages were compared according to the leagues in our study, it was found that the average age of the 3. League was $23.34 \pm 3.50$ years, the average age of the BAL was $23.58 \pm 4.00$ years and the average age of the SAL was $24.78 \pm 5.91$ years. Any statistically significant correlation was not found between the 3 . League, BAL, and SAL in terms of the average ages of the football players. The average age of the football players who participated in the study of 3. League team was detected as $24.75 \pm 5.17$ years by Marangoz (2008). Erkmen et al. (2005) reported that in the study they conducted with the 17 football players playing in the 2 . League, they found the average age of the football players as 20.71 years. When the ABRFP was compared according to the leagues in our study, it was found that the average ABRFP of the 3. League was 13.14 \pm 3.61 years, average ABRFP of the BAL was 12.26 \pm 3.85 years and average ABRFP of the SAL was $12.83 \pm 5.62$ years. Any statistically significant correlation between the 3 . League, BAL, and SAL was not found. When the vertical jump scores were compared according to the leagues in our study, it was found that the average vertical jump score of the 3 . League was $59.08 \pm 7.38 \mathrm{~cm}$, average vertical jump score of the BAL was $56.89 \pm 5.62 \mathrm{~cm}$, and average vertical jump score of the SAL was $53.43 \pm 5.66 \mathrm{~cm}$. In this context, a statistically significant correlation in favor of the 3. League was found between the 3. League and the SAL. In the comparison of anaerobic power according to the leagues in our study, it was found that average anaerobic power of the 3. League was $128.90 \pm 17.13 \mathrm{~kg} . \mathrm{m} / \mathrm{sec}$, average anaerobic power of the BAL was $122.76 \pm 12.25 \mathrm{~kg} . \mathrm{m} / \mathrm{sec}$ and average anaerobic power of SAL was $116.63 \pm 14.64 \mathrm{~kg} . \mathrm{m} / \mathrm{sec}$. In this context, a statistically significant correlation in favor of the 3. League was found between the 3. League and the SAL. In the comparison of shuttle run scores according to the leagues in our study, it was found that the average shuttle run score of the 3. League was $102.43 \pm 16.69$, average shuttle run score of the BAL was $114.85 \pm 13.00$ and average shuttle run score of the SAL was $100.73 \pm 16.86$. Statistically significant correlation between the BAL and the 3. League, and between the BAL and the SAL was detected and it was found that shuttle run scores of the BAL were higher than those of the 3. League and the SAL. When the aerobic capacities were compared according to the leagues in our study, it was found that the average $\mathrm{MaxVO}_{2}$ of the 3. League was $52.47 \pm 5.06 \mathrm{ml} / \mathrm{kg} / \mathrm{min}$, average $\mathrm{MaxVO}_{2}$ of the $\mathrm{BAL}$ was $56.24 \pm 3.59 \mathrm{ml} / \mathrm{kg} / \mathrm{min}$ and average $\mathrm{MaxVO}_{2}$ of the SAL was $52.08 \pm 4.96 \mathrm{ml} / \mathrm{kg} / \mathrm{min}$. A statistically significant correlation was found between the BAL and the 3 . League and between the BAL and the SAL and it was detected that aerobic capacity values of the BAL were higher than those of the 3. League and the SAL. Erkmen et al. (2005) reported the $\mathrm{MaxVO}_{2}$ levels of the athletes as $51.36 \mathrm{ml} / \mathrm{kg} / \mathrm{min}$ after they implemented shuttle run test to the 17 football players playing football in the 2. League of Turkey. In the comparison of leg strength according to the leagues in our study, it was found that the average leg strength of the 3. League was $160.43 \pm 25.20 \mathrm{~kg}$, average leg strength of the BAL was $163.00 \pm 29.75 \mathrm{~kg}$ and average leg strength of the SAL was $132.57 \pm 21.49 \mathrm{~kg}$. Statistically significant correlation between the SAL and the 3. League and between the SAL and the BAL was detected and it was found that leg strength value of the SAL was lower than those of the 3. League and the BAL. In the comparison of back strength according to the leagues in our study, it was found that average back strength of the 3. League was $154.10 \pm 25.82 \mathrm{~kg}$, the average back strength of the BAL was $144.85 \pm 25.92 \mathrm{~kg}$ and average back strength of the SAL was $134.86 \pm 21.49 \mathrm{~kg}$. In this context, a statistically significant correlation in favor of the 3 . League was found between the 3. League and the SAL. In the comparison of right-hand grip strength according to the leagues in our study, it was found that the average right-hand grip strength of the 3 . League was $42.37 \pm 6.83 \mathrm{~kg}$, average right-hand grip strength of the BAL was $42.94 \pm 7.75 \mathrm{~kg}$ and average right-hand grip strength of the SAL was $41.22 \pm 6.02$ $\mathrm{kg}$. Any statistically significant correlation was not found between the 3. League, the SAL, and the BAL in terms of right-hand grip strength. In the comparison of left-hand grip strength according to the leagues in our study, it was found that the average left-hand grip strength of the 3 . League was $41.34 \pm 6.13 \mathrm{~kg}$, average left-hand grip strength of the BAL was $40.82 \pm 7.61 \mathrm{~kg}$ and average left-hand grip strength of the SAL was $40.35 \pm 5.46 \mathrm{~kg}$. Any statistically significant correlation was not found between the 3. League, the SAL, and the BAL in terms of left-hand grip strength. When the literature is reviewed, it is observed that the results of this study resemble those of many studies (Erkmen et al., 2005; Marangoz, 2008). Considering differences that emerged between our study and some studies, we think that these differences occur because of the increases in physical fitness levels as the football progresses continuously and changes in rules that Turkish Football Federation (TFF) make at certain times. For example, for the 2017-2018 seasons, while foreign football players cannot play in the 3. League, they can play in the BAL and the SAL.

Scientific data on today's football develop and change continuously as the sports sciences and possibilities of research progress. In this context, physical characteristics of today's football players also develop in line with the requirements of today's football. When the league variable was examined according to the data obtained, it can be argued that there are different types of football players between the leagues in terms of physical fitness levels.

When the 3. League football players are compared with the other football players, they stand out according to the other 
leagues in terms of height, strength and anaerobic power characteristics. In terms of aerobic capacity, the BAL stands out when compared to the other leagues. When the physical fitness levels of the SAL football players are compared with the other leagues, lower scores were obtained. At the same time, it was observed that the football players who downgraded from being professional to being amateur make amateur leagues such as the BAL and the SAL heterogeneous and the football players playing in the leagues increase their physical and physiological characteristics. It can also be stated that ages and the ages of becoming a registered football player of the players who downgraded from being professional to being amateur are higher.

Taking into account the leagues that the teams play in, it is thought that these kind of researches can be used in transferring of the players, in following the progress of the players and in determining physical and physiological characteristics that the players have, as well as they can be used for creating the contents and planning of the trainings during the preparation period, during the season and at the end of the season. Based on the results of our study, it can be suggested that the football players who played at amateur level only, give weight to the trainings aimed at developing anaerobic power, leg and back strengths besides general strength, general endurance, and core trainings in order for them to be able to play football at professional level. It is thought that with extensive and intensive interval, core and combined training methods, anaerobic power, leg and back strengths of the football players at this status will be able to increase to upper levels. It is projected that the football players, who play in the Super Amateur League and have a goal of playing in the upper leagues, will attain their goals easily if they do trainings at upper levels, prepare themselves to upper leagues and do comprehensive and efficient trainings.

\section{Acknowledgment}

We thank Akdeniz University Scientific Research Projects Coordination Unit for our project that was supported by 2017-2022 project number. We also thank the administrators, the coaches, and the players of Kemer Belediyespor and Kızılcabölükspor from the 3. League, Municipality of Bucak Oğuzhanspor and Kepez Belediyespor from the Regional Amateur League, and Antalya Sanayispor and Konyaaltı Belediyespor who participated in our Master's Thesis Project in the 2017-2018 season.

\section{References}

Acıkada, C., Hazır, T., Ascı, A., Turnagol, H., \& Ozkara, A. (1999). Bir ikinci lig futbol takiminin sezon oncesi hazirlik doneminde fiziksel ve fizyolojik profili (Lit. Physical and physiological profile of a second league football team during pre-season preparation method). Futbol Bilim ve Teknoloji Dergisi, 1, 14-20.

Aslan, C. S., \& Koc, H. (2015). Amator Futbolcularin Secilmis Fiziksel, Fizyolojik ve Motorik Ozelliklerinin Mevkilerine Gore Karsilastirilmasi (Lit. Comparison of Selected Physical, Physiological and Motoric Characteristics of Amaeteur Football Players According to Their Positions). Celal Bayar University. Beden Egitimi ve Spor Bilimleri Dergisi. ISSN: 2149-1046.

Bangsbo, J. (1994). Energy demands in competitive soccer. Journal of Sport Science, 12, 5-12.

Bayrak, M. (2011). Sporu Birakmis Profesyonel Futbolcularin Depresyon Duzeylerinin Yasam Kalitesi Acisindan Degerlendirilmesi (Lit. An Evaluation of Depression Levels of Professional Football Players Who Quitted In Terms of Quality of Life). Unpublished Doctoral Dissertation. On Dokuz Mayis University Institute of Health Sciences.

Bizati, O. (2013). Profesyonel Futbolcularin Fiziksel ve Fizyolojik Degerlendirmelerinde Kullanilan Farkli Yontemlerin Karsilastirilmasi (Lit. A Comparison of Different Methods Used in Physical and Physiological Evaluations of Professional Football Players). Unpublished Doctoral Dissertation. Ankara University: Institute of Health Sciences.

Bugdayc1, S. (2000). Profesyonel Futbolcularla Amator Futbolcularin Fiziksel Parametrelerinin Karsilastirmasi (Lit. A Comparison of Physical Parameters of Professional and Amateur Football Players). Master's Thesis, Selcuk University Institute of Health Sciences, Konya.

Davis, J. A., Brewer, J., \& Atkin, D. (1992). Pre-season Physiological Characteristics of English First and Second Division Soccer Players, J Sports SCI. https://doi.org/10.1080/02640419208729950

Erkmen, N., Kaplan, T., \& Taskin, H. Profesyonel Futbolcularin Hazirlik Sezonu Fiziksel ve Fizyolojik Parametrelerinin Tespiti ve Karsilastirilmasi (Lit. Detection and Comparison of Physical and Physiological Parameters of Professional Football Players During the Preparation Season). Spormetre Beden Egitimi ve Spor Bilimleri Dergisi. 3(4), 137-144. https://doi.org/10.1501/Sporm_0000000056

Garganta, J., Maria, J., Silvia, R., \& Natal, A. (1992). A Comparative Study of Explosive Leg Strength in Elite and Nonelite Young Soccer Players.

Gordon, C. C., Churchill, T., Clauser, C. E., Bradtmiller, B., Mcconville, J. T., Tebbetts, I., \& Walker, R. A. (1988). 
Anthropometric Survey of U. S. Army Personnel: Summary Statistics Interim Report. Technical report: Natick/ TR-89/027, Natick, MA: U.S. Army Natick RD\&E Center.

Gunay, M., \& Yuce, A. (2008). Futbol Antrenmaninin Bilimsel Temelleri (Lit. Scientific Foundations of Football Training). Ankara, Gazi Kitabevi, 61.

Karatepe, R. (2009). Genc futbolcularda tekrarli sprint derecelerinin aerobik güc ile iliskisinin incelenmesi (Lit. An Examination of Relationship of Repeated Sprint Grades with Aerobic Power in Young Football Players). Master's Thesis, Ankara University, Institute of Health Sciences Üniversitesi.

Maranc1, B., \& Muniroglu S. (2001). Futbol Kalecileri ve Diger Mevkilerde Bulunan Oyuncularin Motorik Ozellikleri, Reaksiyon Zamanlari ve Vucut Yag Yuzdelerinin Karsilastirilmasi (Lit. A Comparison of Motoric Characteristics, Reaction Times and Body Fat Percentages of Football Goalkeepers and Players Playing in Other Positions). Gazi Beden Egitimi ve Spor Bilimleri Dergisi, 6(3), 13-26.

Marangoz, İ. (2008). Kahramanmaras ve Siirt Spor Profesyonel Futbol Takimlarinin Musabaka Doneminde Secilmis Bazi Fiziksel ve Fizyolojik Ozelliklerinin Karsilastirilmasi (Lit. A Comparison of Selected Physical and Physiological Characteristics of Kahramanmaras and Siirt Spor Professional Football Teams During the Football Season). (Master's Thesis). Kahramanmaras Sutcu İmam University Institute of Social Sciences, Kahramanmaras.

Meckel, Y., Machnai, O., \& Eliakim, A. (2009). Relationship Among Repeated Sprint Tests, Aerobic Fitness, and Anaerobic Fitness in Elite Adolescent Soccer Players. Journal of Strength and Conditioning Research, 23(1), 163-169. https://doi.org/10.1519/JSC.0b013e31818b9651

Ozer, K. (1993). Antropometri Sporda Morfolojik Planlama (Lit. Morphological Planning in Sports), 66.

Ramsbottom, R., Brewer, J., \& Williams, C. (1988). A ProgressiveShuttle Run Test To Estimate Maximal Oxygen Uptake. Brit J.Sports Med., 22(4), 141-144. https://doi.org/10.1136/bjsm.22.4.141

Roescher C. R., Elferink-Gemser, M. T., Huijgen, B. C., \& Visscher, C. (2010). Soccer Endurance Development in Professionals. Int. J. Sports Med., 31(3), 174-179. https://doi.org/10.1055/s-0029-1243254

Tamer, K. (2000). Sporda Fiziksel-Fizyolojik Performansin Olculmesi ve Degerlendirilmesi (Lit. A Measurement and Evaluation of Physical-Physiological Performance in Sports), Bagirgan Yayinevi, Ankara, 2000.

Weineck, J. (2011). Optimales Fussball Training. Spitta Verlag GmbH and Co.; 4., über arb. A. Edition. 2011.

Zorba, E., \& Saygin, O. (2009). Fiziksel Aktivite ve Fiziksel Uygunluk (Lit. Physical Activity and Physical Fitness). İnceler Ofset. İstanbul.

\section{Copyrights}

Copyright for this article is retained by the author(s), with first publication rights granted to the journal.

This is an open-access article distributed under the terms and conditions of the Creative Commons Attribution license which permits unrestricted use, distribution, and reproduction in any medium, provided the original work is properly cited. 